\title{
THE RENAL FUNCTION OF INFANTS DELIVERED OF TOXAEMIC MOTHERS
}

\author{
BY \\ D. C. A. BEVIS and S. F. SCHOFIELD \\ From the Obstetrical and Neonatal Departments, St. Mary's Hospital, Manchester
}

(Received for Publication April 28, 1950)

Much has been written in the past on the effects of the toxaemias of pregnancy on the maternal organism, but surprisingly little has been done to investigate the effects of these diseases on the foetus. The few reviews of the subject have been concerned chiefly with the general effects on the foetus and hardly any have considered in detail specific points of foetal and neonatal pathology.

The present investigation of the kidney of the foetus and newborn infant has proceeded along three main lines: (1) anatomical considerations; (2) physiological considerations; (3) indirect observations of kidney function, especially the production of hypertension.

\section{Anatomical Considerations}

The gross anatomy of the kidney was studied in 57 cases of foetal and neonatal death, of which 19 were of infants delivered of mothers showing a clinically severe degree of pre-eclampsia at the time of delivery. No gross lesions were apparent and the degree of gross development appeared to be comparable in both classes of infants. To confirm this last point, the kidney weight was plotted against the body weight using a logarithmic scale (Fig. 1) as described by Huxley (1932). It will be seen that

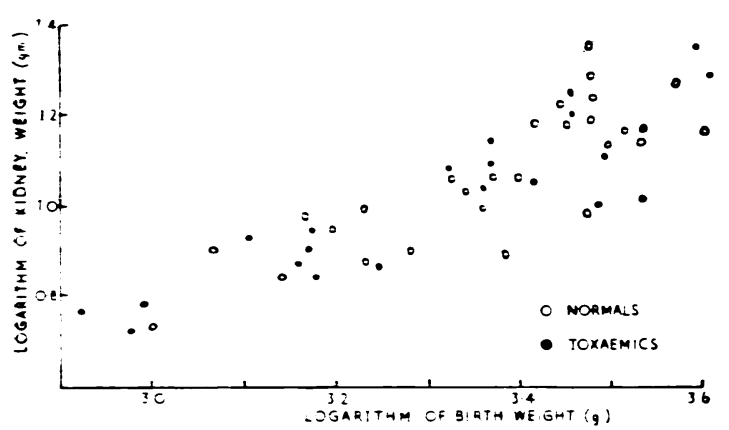

FIG. 1.-Gross development of the kidney. there is little difference between the two groups of infants, and statistical analysis confirms that the growth of the kidney proceeds at the same rate in both groups of infants.

A study of the histology of the kidneys was made special note being taken of the development of the glomeruli, this being a reliable guide to the maturity of the kidney (Potter and Thierstein, 1943). The development of the glomerulus has been described by Gruenwald and Popper (1940) who state that in the early stages of development both layers of Bowman's capsule consist of cuboidal or high columnar epithelium. In the more mature glomerulus the parietal layer decreases in height except in the vicinity of the opening of the tubule. In the young glomerulus the entire glomerular tuft forms an undivided globule covered by a uniform layer of high columnar epithelium; the lumen of the glomerular loops is partially visible, the loops are in close contact with each other and no free spaces are visible between them. At birth the glomerular loops expand and contain more blood cells; between the individual loops, clefts are visible which proceed towards the vascular pole and separate the glomerulus into three to eight lobules. The original continuous layer of high columnar cells is broken by the clefts and the loops are incompletely covered by epithelium. Further development leads to the stage at which most of the completely expanded loops show small islands only of epithelium on their surface and only on the peak is the continuous layer of high columnar epithelium visible.

In the present investigation the development of the glomeruli was judged by the following criteria: (1) the character of the epithelium of the visceral layer of Bowman's capsule; (2) the presence of 'tufting '; (3) the presence of fibrous tissue laid down as a skeleton for 'tufting '; (4) the degree of development of the blood vessels. This last characteristic was sometimes difficult to judge, as some of the kidneys were congested at death. In 


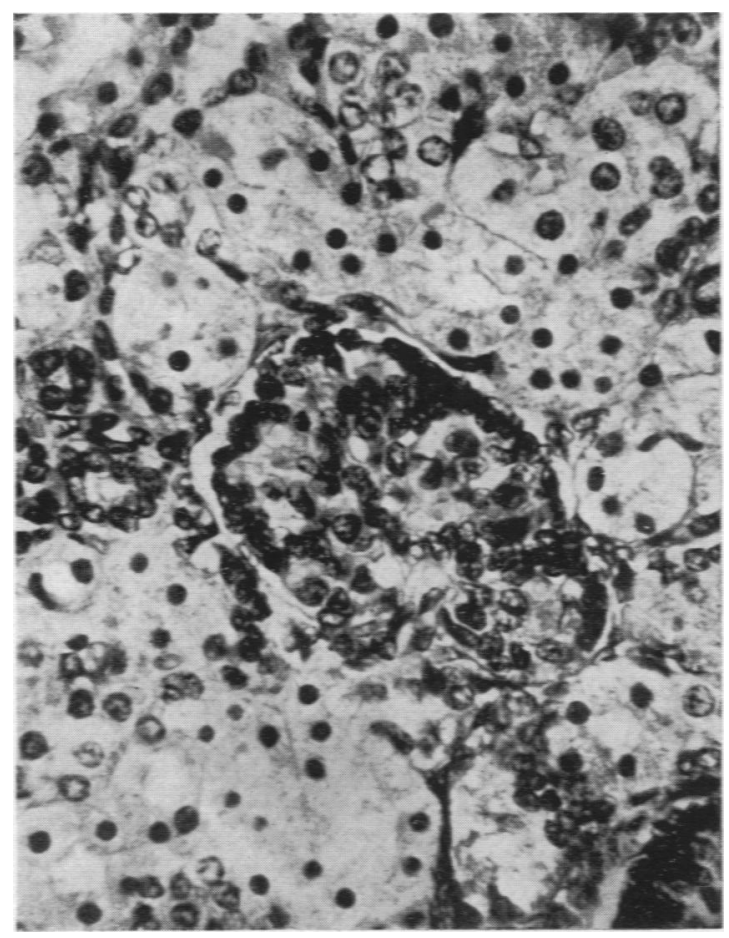

Fig. A.--Immature glomerulus. Note that Bowman's capsule is almost intact and is composed of large cuboidal cells. The tufted arrangement is just becoming apparent. (Haematoxylin and eosin $\times 420$ ).

most cases, however, it was possible to make an attempt at grading.

Unselected sections were examined, having been stained with haemalum, azan, and van Gieson. Particular attention was paid to the glomeruli of the cortico-medullary junction as these were the most fully developed (Gruenwald and Popper, 1940 ; Kampmeier, 1926). Those in the subcapsular zone were, however, examined as these give an idea of the 'functional age' of the kidney (Potter and Thierstein, 1943). The material used was the same as that for the kidney weights and the results are recorded in Table 1.

No lesions were seen in the kidneys comparable with those found in women dying of pre-eclampsia and eclampsia. This question has been considered by Raubitschek (1914) and by Tyson and Bowman (1931). Cases described by these writers appear to be cases of haemolytic disease of the newborn, a condition not recognized at the time of writing. The absence of typical lesions is further confirmation of the finding of Brash (1949). No difference is apparent between the two groups of infants, and the findings confirm most of the work of Gruenwald and Popper but do not confirm that at birth there is a sudden rupture of the glomerular tufts: the process appears to be a continuous one and much more like that postulated by Smith (1945) on theoretical grounds.

\section{Physiological Considerations}

It has been stated many times that the infantile kidney is inefficient when compared with the adult kidney (McCance and Young, 1941; Young, Hallum, and McCance, 1941). This is perhaps not surprising as the neonatal kidney has to adjust its function while that of the adult has reached more or less of an equilibrium. Tests of kidney function are notoriously difficult to interpret as it is often uncertain what function of the kidney is being measured. As the urea clearance test is practicable and does not entail the administration of any test substance to the infant, that was adopted as the best test in the circumstances.

Urine was collected in an apparatus modified from that described by Thomson (1944) and illustrated in Fig. 2. The rubber bulb has an opening cut in one side and this fits over the genitalia and is attached to the infant by two rubber straps. The

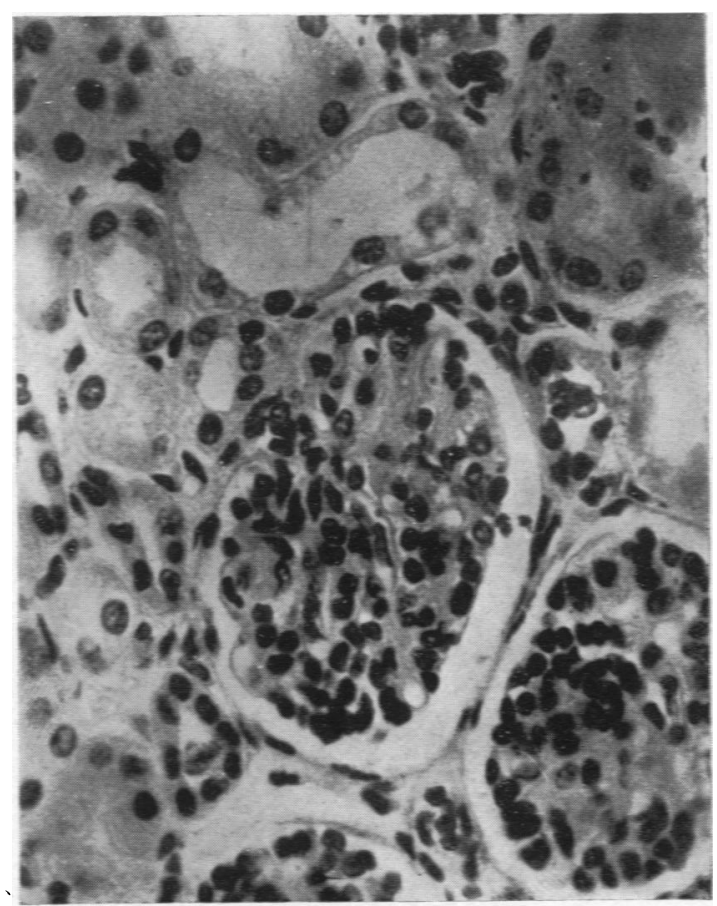

FG. B.-Mature glomerulus in which Bowman's capsule has almost disappeared and only a few large cells are present on the surface. The tufted arrangement is now quite clear. (Haemotoxylin and eosin $\times 420$ ). 
TABLE 1

HistoLOGY OF THE GLOMERULUS

\begin{tabular}{|c|c|c|c|c|c|}
\hline \multirow{3}{*}{$\begin{array}{c}\text { Degree of Tufting } \\
\text { Babies under } 2 \cdot 5 \\
\text { Toxaemics } \\
\text { Controls }\end{array}$} & \multirow{3}{*}{$\begin{array}{l}\text { kg. } \\
\cdots \\
\cdots\end{array}$} & \multicolumn{3}{|c|}{ No. of Cases } & \multirow[b]{2}{*}{$\mathbf{P}^{*}$} \\
\hline & & & Poor & Good & \\
\hline & & $\begin{array}{l}\cdots \\
\cdots\end{array}$ & $\begin{array}{l}8 \\
6\end{array}$ & $\begin{array}{r}6 \\
12\end{array}$ & 0.118 \\
\hline \multirow{3}{*}{$\begin{array}{c}\text { Over } 2.5 \mathrm{~kg} . \\
\text { Toxaemics } \\
\text { Normals }\end{array}$} & & & & & \\
\hline & .. & .. & 3 & 2 & \\
\hline & . & .. & 3 & 15 & 0.081 \\
\hline \multicolumn{6}{|c|}{ Fibrous Arrangement in Tufts } \\
\hline Toxaemics & .. & .. & 4 & 7 & \\
\hline Normals & .. & 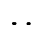 & 1 & 13 & 0.087 \\
\hline Over $2.5 \mathrm{~kg}$. & & & & & \\
\hline $\begin{array}{l}\text { loxaemics } \\
\text { Normals }\end{array}$ & $\cdots$ & .. & 1 & $\begin{array}{r}4 \\
15\end{array}$ & 0.389 \\
\hline
\end{tabular}

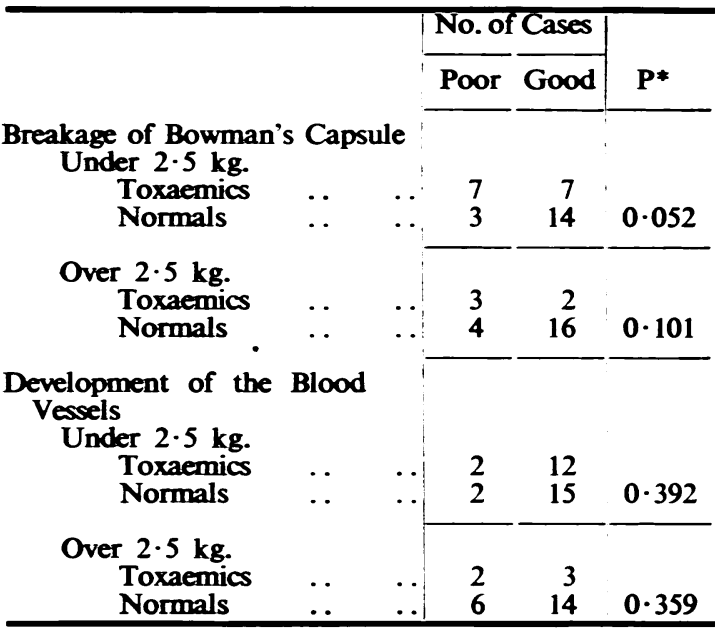

- In no case is $P$ less than 0.05 and therefore there is no statistical difference between the toxaemic and normal groups, although at first sight there would appear to be an appreciable difference. ' $P$,' the probability that the readings occurred by chance, has been calculated by Fisher's ' exact' method.

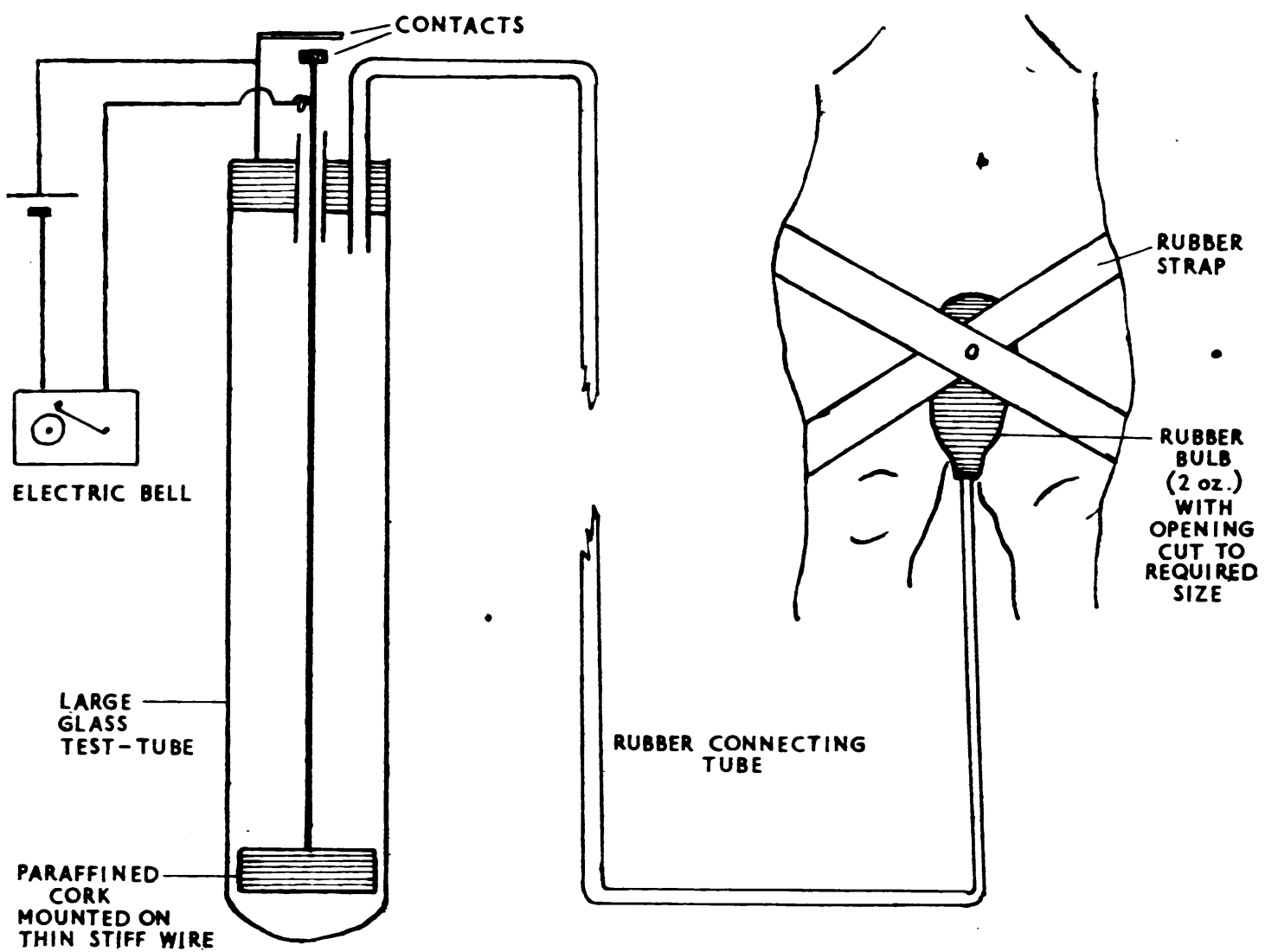

Fig. 2.-Apparatus used to collect urine for urea clearance tests. 
size of the opening is determined by experiment, it being important to secure a water-tight fit without causing too much pressure on the genitalia. The urine passes to the recording tube and lifts the cork to close the electrical contacts and ring the bell. The apparatus is connected to the infant and left until the child micturates; the time is noted and the specimen discarded; at the next micturition the time is again noted and a specimen of blood taken for the estimation of the blood urea. Care is taken to ensure that the connecting tubing is emptied of urine each time a specimen is obtained. Although the apparatus is rather crude, it appears to be quite efficient and causes very little discomfort to babies of either sex.

The blood urea and urine urea concentrations

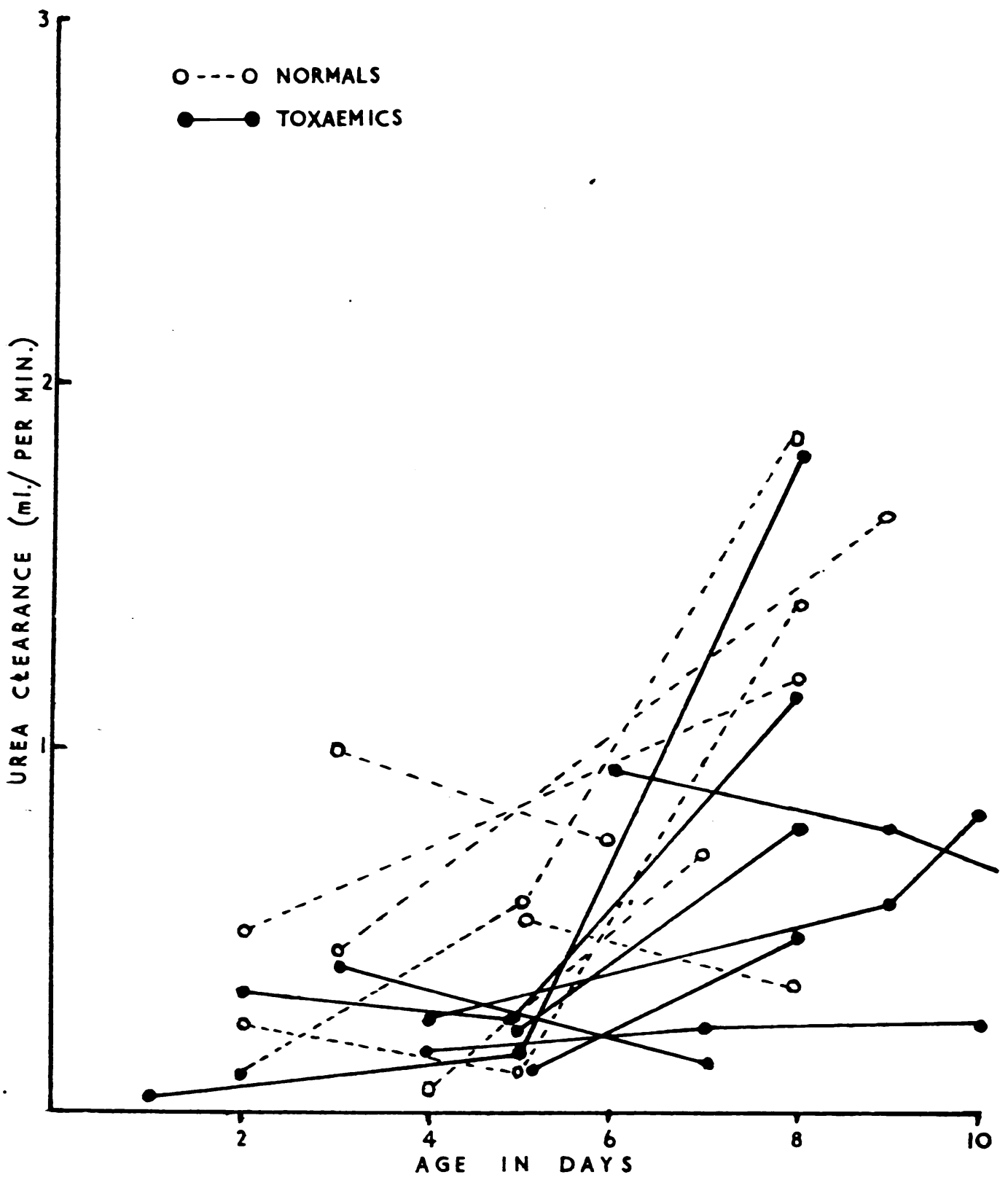

Fig. 3.-Urea clearances. 
were estimated by the colorimetric methods described by King (1946). No filtrations were carried out as described by King, specimens being centrifuged as filter-paper contains substances that give a reaction to Nessler's reagent (Harrison, 1947).

Eight normal babies and eight babies delivered of mothers with a severe clinical degree of preeclampsia were investigated. The toxaemic infants were almost consecutive cases and were all apparently well; only those infants are considered on whom at least two determinations were made.

The urea clearances are plotted in Fig. 3. It will be seen that, in general, the clearances are of the same order, and in most cases, their values rise as the infant grows older. The values are much the same as those obtained by other workers (McCance and Young, 1941; Young, et al., 1941; Thomson, 1944 and 1949). Correction for surface area is

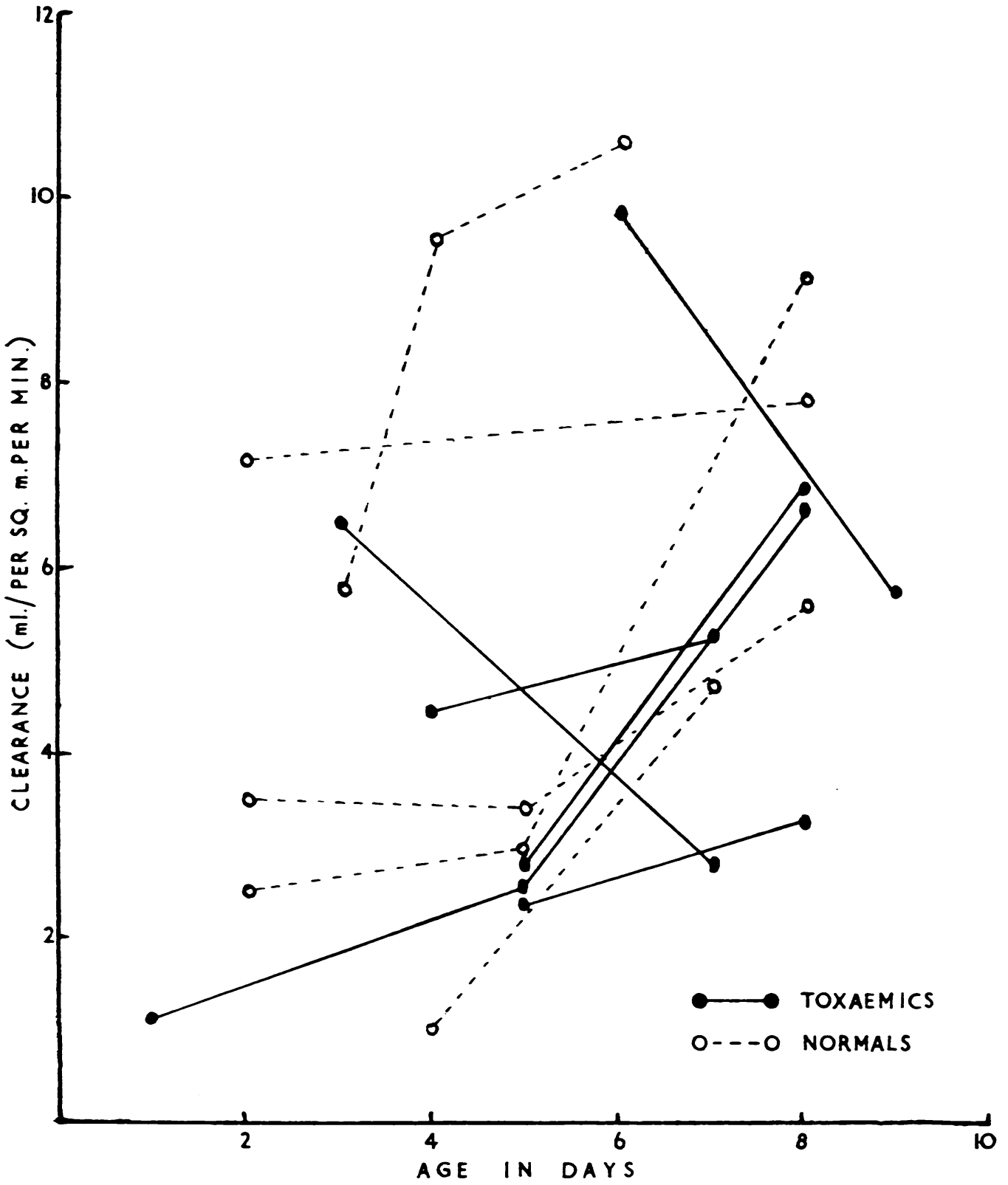

FIG. 4.-Corrected urea clearances. 
TABLE 2

Normals

Urea Clearances in Normal and Toxaemic Babies

\begin{tabular}{|c|c|c|c|c|c|c|c|c|}
\hline \multirow{2}{*}{ Baby } & \multirow{2}{*}{$\begin{array}{l}\text { Weight } \\
\text { (kg.) }\end{array}$} & \multirow{2}{*}{$\begin{array}{l}\text { Length } \\
\text { (cm.) }\end{array}$} & \multirow{2}{*}{$\begin{array}{c}\text { Surface } \\
\text { Area } \\
\text { (sq. m.) }\end{array}$} & \multirow{2}{*}{$\begin{array}{c}\text { Age } \\
\text { (days) }\end{array}$} & \multicolumn{2}{|c|}{ Urea (mg./100 ml.) } & \multirow{2}{*}{$\begin{array}{c}\text { Minute } \\
\text { Volume } \\
\text { (ml.) }\end{array}$} & \multirow{2}{*}{$\begin{array}{c}\text { Urea } \\
\text { Clearance }\end{array}$} \\
\hline & & & & & Blood & Urine & & \\
\hline 1 & $4 \cdot 27$ & $53 \cdot 0$ & $0 \cdot 24$ & $\begin{array}{l}4 \\
7\end{array}$ & $\begin{array}{l}21 \cdot 9 \\
22 \cdot 5\end{array}$ & $\begin{array}{l}111 \\
136\end{array}$ & $\begin{array}{l}0 \cdot 012 \\
0 \cdot 117\end{array}$ & $\begin{array}{l}0.061 \\
0.71\end{array}$ \\
\hline 2 & & & & $\begin{array}{l}3 \\
4 \\
6\end{array}$ & $\begin{array}{l}36 \cdot 0 \\
29 \cdot 4 \\
91 \cdot 6\end{array}$ & $\begin{array}{l}445 \\
473 \\
349\end{array}$ & $\begin{array}{l}0.034 \\
0.063 \\
0 \cdot 186\end{array}$ & $\begin{array}{l}0.42 \\
1.02 \\
0.71\end{array}$ \\
\hline \multirow[t]{2}{*}{3} & $2 \cdot 58$ & $50 \cdot 5$ & $0 \cdot 18$ & $\begin{array}{l}3 \\
9\end{array}$ & $\begin{array}{l}38 \cdot 9 \\
35 \cdot 9\end{array}$ & $\begin{array}{l}890 \\
275\end{array}$ & $\begin{array}{l}0.019 \\
0.212\end{array}$ & $\begin{array}{l}0.43 \\
1.65\end{array}$ \\
\hline & $2 \cdot 91$ & $50 \cdot 5$ & $0 \cdot 19$ & $\begin{array}{l}2 \\
5 \\
8\end{array}$ & $\begin{array}{r}66 \cdot 8 \\
37 \cdot 2 \\
108 \cdot 0\end{array}$ & $\begin{array}{l}604 \\
642 \\
470\end{array}$ & $\begin{array}{l}0.029 \\
0 \cdot 007 \\
0 \cdot 325\end{array}$ & $\begin{array}{l}0 \cdot 26 \\
0 \cdot 12 \\
1 \cdot 40\end{array}$ \\
\hline 5 & $3 \cdot 46$ & $50 \cdot 5$ & 0.20 & $\begin{array}{l}2 \\
5 \\
8\end{array}$ & $\begin{array}{l}53 \cdot 8 \\
47 \cdot 2 \\
23 \cdot 0\end{array}$ & $\begin{array}{l}544 \\
131 \\
209\end{array}$ & $\begin{array}{l}0.012 \\
0 \cdot 200 \\
0 \cdot 206\end{array}$ & $\begin{array}{l}0.12 \\
0.55 \\
1 \cdot 87\end{array}$ \\
\hline 6 & & & & 2 & $\begin{array}{l}33 \cdot 6 \\
36 \cdot 7\end{array}$ & $\begin{array}{l}362 \\
470\end{array}$ & $\begin{array}{l}0.003 \\
0.270\end{array}$ & $\begin{array}{l}0.03 \\
3.46\end{array}$ \\
\hline 7 & $3 \cdot 35$ & $53 \cdot 0$ & 0.21 & $\begin{array}{l}2 \\
8\end{array}$ & $\begin{array}{l}28 \cdot 6 \\
33 \cdot 8\end{array}$ & $\begin{array}{l}542 \\
282\end{array}$ & $\begin{array}{l}0 \cdot 031 \\
0 \cdot 136\end{array}$ & $\begin{array}{l}0.59 \\
1 \cdot 16\end{array}$ \\
\hline 8 & 3.06 & $45 \cdot 5$ & $0 \cdot 18$ & $\begin{array}{l}5 \\
8\end{array}$ & $\begin{array}{l}28 \cdot 2 \\
21 \cdot 4\end{array}$ & $\begin{array}{r}1,172 \\
212\end{array}$ & $\begin{array}{l}0.013 \\
0.035\end{array}$ & $\begin{array}{l}0.54 \\
0.35\end{array}$ \\
\hline
\end{tabular}

Toxaemics

\begin{tabular}{|c|c|c|c|c|c|c|c|c|}
\hline 9 & 3.09 & $53 \cdot 0$ & $0 \cdot 20$ & $\begin{array}{l}5 \\
8\end{array}$ & $\begin{array}{l}61 \cdot 8 \\
44 \cdot 5\end{array}$ & $\begin{array}{l}439 \\
522\end{array}$ & $\begin{array}{l}0.032 \\
0.067\end{array}$ & $\begin{array}{l}0 \cdot 23 \\
0.78\end{array}$ \\
\hline 10 & $2 \cdot 33$ & $48 \cdot 0$ & $0 \cdot 17$ & $\begin{array}{l}5 \\
8\end{array}$ & $\begin{array}{l}62 \cdot 5 \\
36 \cdot 7\end{array}$ & $\begin{array}{l}412 \\
141\end{array}$ & $\begin{array}{l}0 \cdot 021 \\
0 \cdot 127\end{array}$ & $\begin{array}{l}0 \cdot 14 \\
0.49\end{array}$ \\
\hline 11 & $3 \cdot 21$ & 53.0 & 0.21 & $\begin{array}{l}1 \\
5 \\
8\end{array}$ & $\begin{array}{l}63 \cdot 0 \\
64 \cdot 5 \\
77 \cdot 3\end{array}$ & $\begin{array}{l}479 \\
324 \\
461\end{array}$ & $\begin{array}{l}0.005 \\
0.034 \\
0.300\end{array}$ & $\begin{array}{l}0.04 \\
0 \cdot 17 \\
1 \cdot 80\end{array}$ \\
\hline 12 & $2 \cdot 92$ & $48 \cdot 0$ & $0 \cdot 19$ & $\begin{array}{l}3 \\
7\end{array}$ & $\begin{array}{r}38 \cdot 9 \\
103 \cdot 0\end{array}$ & $\begin{array}{l}730 \\
600\end{array}$ & $\begin{array}{l}0.023 \\
0.018\end{array}$ & $\begin{array}{l}0.43 \\
0 \cdot 10\end{array}$ \\
\hline 13 & $4 \cdot 08$ & $53 \cdot 0$ & $0 \cdot 23$ & $\begin{array}{r}4 \\
9 \\
10\end{array}$ & $\begin{array}{r}119 \cdot 5 \\
31 \cdot 7 \\
36 \cdot 8\end{array}$ & $\begin{array}{r}1,845 \\
358 \\
446\end{array}$ & $\begin{array}{l}0.019 \\
0.051 \\
0.066\end{array}$ & $\begin{array}{l}0 \cdot 29 \\
0 \cdot 57 \\
0 \cdot 81\end{array}$ \\
\hline 14 & $2 \cdot 27$ & $45 \cdot 5$ & $0 \cdot 16$ & $\begin{array}{r}6 \\
9 \\
12\end{array}$ & $\begin{array}{l}80 \cdot 0 \\
47 \cdot 0 \\
62 \cdot 0\end{array}$ & $\begin{array}{r}1,340 \\
335 \\
606\end{array}$ & $\begin{array}{l}0.057 \\
0.109 \\
0.031\end{array}$ & $\begin{array}{l}0.95 \\
0 \cdot 77 \\
0 \cdot 30\end{array}$ \\
\hline 15 & $2 \cdot 61$ & $48 \cdot 0$ & $0 \cdot 18$ & $\begin{array}{r}4 \\
7 \\
10\end{array}$ & $\begin{array}{l}69 \cdot 3 \\
59 \cdot 7 \\
84 \cdot 0\end{array}$ & $\begin{array}{l}815 \\
468 \\
128\end{array}$ & $\begin{array}{l}0.013 \\
0.027 \\
0.148\end{array}$ & $\begin{array}{l}0 \cdot 16 \\
0 \cdot 21 \\
0 \cdot 23\end{array}$ \\
\hline 16 & $3 \cdot 94$ & $53 \cdot 0$ & $0 \cdot 22$ & $\begin{array}{l}2 \\
5 \\
8\end{array}$ & $\begin{array}{l}69 \cdot 3 \\
37 \cdot 2 \\
25 \cdot 8\end{array}$ & $\begin{array}{l}144 \\
362 \\
109\end{array}$ & $\begin{array}{l}0 \cdot 164 \\
0.027 \\
0.273\end{array}$ & $\begin{array}{l}0 \cdot 34 \\
0 \cdot 26 \\
1 \cdot 15\end{array}$ \\
\hline
\end{tabular}


shown in Fig. 4, and this, too, shows no difference between the two groups of infants.

It will be noted from Table 2 that the blood urea concentration of the toxaemic infants is higher than that of the controls: these concentrations are plotted in Fig. 5 and the difference has been confirmed by analysis of the means over the different days. The blood urea and urine urea concentrations must be greatly influenced by the protein intake of the subject, and although it was impossible to test-feed each baby during this investigation, consideration of the diets and the general condition of the individual babies does not lead us to suppose that feeding is the explanation of this finding. A similar consideration of loss of body weight over this period does not point to any significant difference

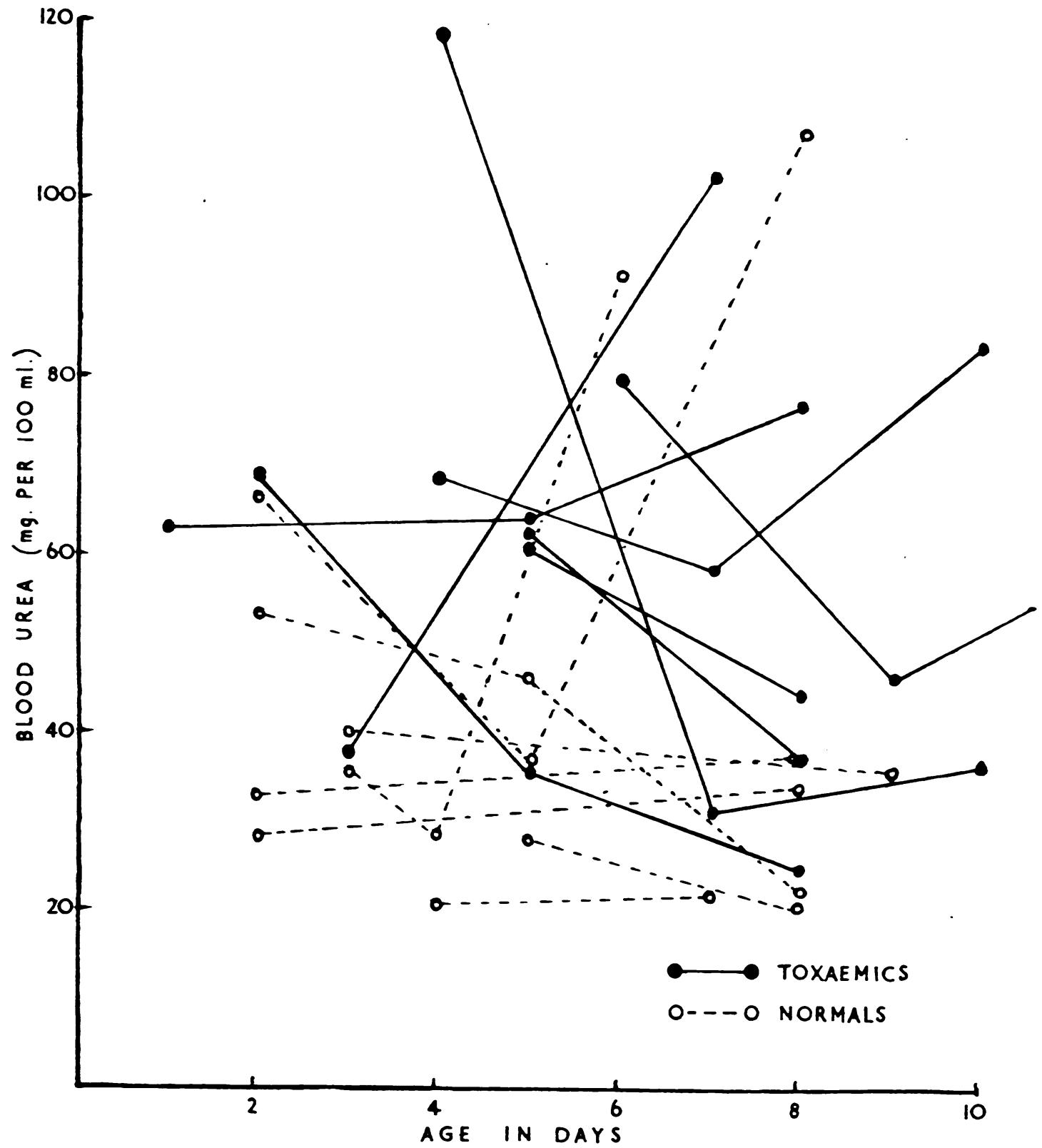

Fig. 5.-Blood urea concentrations. 
between the two groups of babies. It is also unlikely that this finding is related to the state of the mother at the delivery, for the blood urea is never raised in pure pre-eclamptic toxaemia. It has been suggested (Young, et al., 1941) that the raised blood urea in premature infants may be due to the low minute volume. This is not the case here, as may be seen when the blood urea is plotted against the actual and the corrected minute volumes (Figs. 6 and 7); low volumes are present in both groups but the blood urea is persistently higher in the toxaemic group.

The occurrence of albuminuria was investigated in both groups of infants, and the results in 67 babies are shown in Table 3 . There is no significant difference between the two groups and although the occurrence is common, the findings of Ewald (1916) and Salmi (1936) are not confirmed, these authors reporting albuminuria in 75 to $80 \%$ of infants investigated.

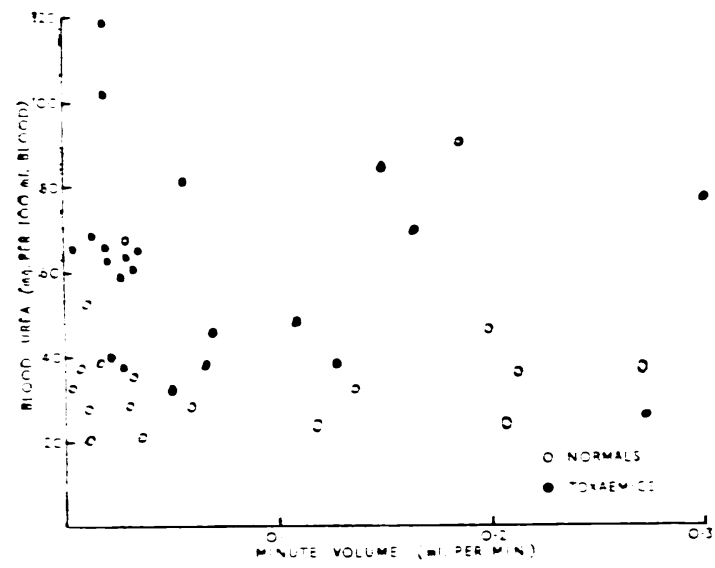

Fig. 6.-Blood urea minute volume.

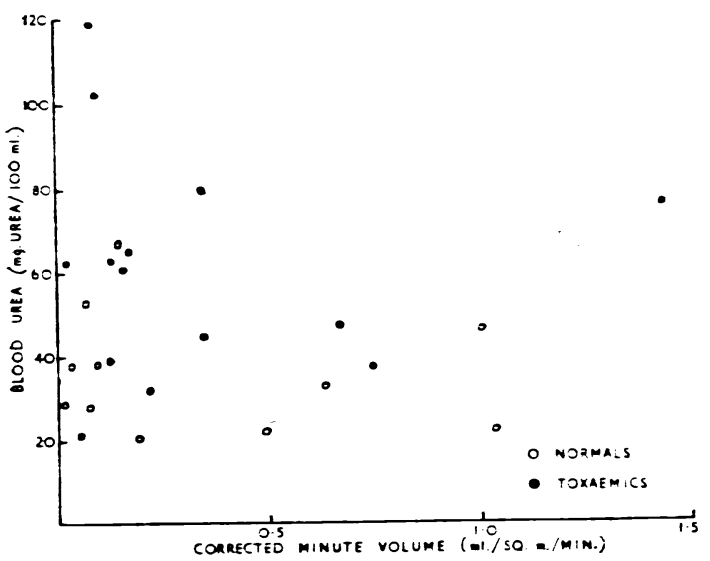

Fig. 7.-Blood urea corrected minute volume.
TABLE 3

INCIDENCE OF Albuminuria

\begin{tabular}{|c|c|c|c|c|c|}
\hline & & & \multicolumn{3}{|c|}{ Albumin } \\
\hline & & & Present & Absent & Total \\
\hline Normals & & $\ldots$ & 22 & 30 & 52 \\
\hline Toxaemics & $\cdots$ & $\cdots$ & 12 & 5 & 17 \\
\hline Total & .. & . & 34 & 35 & 69 \\
\hline
\end{tabular}

$\mathrm{x}^{2}$ (Yates's correction) $=3.05 . \quad \mathrm{P}$ is between 0.1 and 0.05 . There is no significant difference between the two groups of infants.

\section{Indirect Observations}

From time to time attempts have been made to study the neonatal blood pressure, but as the pulsations of the infantile arteries are feeble, palpatory and auscultatory methods are difficult and give no idea of the diastolic pressure (Browne and Dodds, 1936; Brash, 1949). The oscillometric method has therefore proved to be the most satisfactory (Rucker and Connell, 1924; Salmi, 1936; Woodbury, Robinow, and Hamilton, 1938). The size of the cuff influences the recorded blood pressure quite considerably (Woodbury, et al., 1938; Smith, 1945) and it has been found that when a cuffe $2.5 \mathrm{~cm}$. wide is used, the blood pressure recorded by a cannula in the umbilical artery is the same as that recorded oscillometrically. The blood pressures in this study were therefore recorded with a Pachon oscillometer and a $2 \cdot 5 \mathrm{~cm}$. cuff. The criteria of systolic and diastolic pressure were those described by Norris, Bazett, and McMillan (1928). Readings were taken on the second, fourth, and seventh days of life with the babies supine and quiet although not asleep.

Ten normal babies and 10 babies delivered of mothers with clinically severe pre-eclampsia at delivery were investigated. In no case was a baby investigated if the mother gave any history suggestive of renal disease before pregnancy.

The results are given in Table 4, and it will be seen that on the second day of life both the systolic and diastolic pressures of the toxaemic group are significantly higher than those of the controls. On the succeeding days there is no difference between the two groups. This finding is in accordance with that described by Rucker and Connell (1924), but not with other writers using similar methods or material (Haselhorst, 1929; Woodbury, et al., 1938; Dexter and Weiss, 1941; Brash, 1949). It would appear that some factor is acting at birth and that its effects wear off as the child gets older. 
TABLE 4

Blood Pressures in Normal and Toxaemic Groups

\begin{tabular}{|c|c|c|c|c|c|c|c|}
\hline \multicolumn{4}{|c|}{ Normals } & \multicolumn{4}{|c|}{ Toxaemics } \\
\hline Baby & Day 2 & Day 4 & Day 7 & Baby & Day 2 & Day 4 & Day 7 \\
\hline $\begin{array}{r}1 \\
2 \\
3 \\
4 \\
5 \\
6 \\
7 \\
8 \\
9 \\
10\end{array}$ & $\begin{array}{l}60 / 35 \\
50 / 30 \\
70 / 55 \\
60 / 40 \\
65 / 45 \\
65 / 45 \\
60 / 35 \\
70 / 40 \\
75 / 40 \\
90 / 60\end{array}$ & $\begin{array}{r}85 / 65 \\
85 / 50 \\
100 / 60 \\
75 / 50 \\
90 / 75 \\
70 / 50 \\
80 / 65 \\
90 / 50 \\
\mathbf{9 0 / 5 0} \\
90 / 65\end{array}$ & $\begin{array}{l}85 / 70 \\
85 / 55 \\
90 / 60 \\
85 / 50 \\
90 / 75 \\
75 / 55 \\
85 / 65 \\
90 / 60 \\
95 / 60 \\
95 / 65\end{array}$ & $\begin{array}{l}11 \\
12 \\
13 \\
14 \\
15 \\
16 \\
17 \\
18 \\
19 \\
20\end{array}$ & $\begin{array}{r}85 / 55 \\
100 / 75 \\
80 / 50 \\
85 / 50 \\
85 / 65 \\
90 / 70 \\
80 / 65 \\
75 / 50 \\
100 / 70 \\
95 / 50\end{array}$ & $\begin{array}{r}110 / 75 \\
105 / 70 \\
95 / 65 \\
95 / 60 \\
80 / 50 \\
105 / 85 \\
110 / 80 \\
80 / 60 \\
100 / 80 \\
80 / 60\end{array}$ & $\begin{array}{r}100 / 70 \\
75 / 55 \\
100 / 65 \\
115 / 90 \\
75 / 50 \\
100 / 80 \\
100 / 80 \\
80 / 60 \\
95 / 80 \\
85 / 60\end{array}$ \\
\hline
\end{tabular}

Mean Pressures

\begin{tabular}{|c|c|c|c|c|c|c|}
\hline Systolic & & & & Day 2 & Day 4 & Day 7 \\
\hline & $\begin{array}{l}\text { Normals } \\
\text { Toxaemics }\end{array}$ & $\begin{array}{l}\cdots \\
\cdots\end{array}$ & $\begin{array}{l}. \\
\cdots\end{array}$ & $\begin{array}{l}66 \cdot 5 \pm 10 \cdot 8 \\
87 \cdot 5 \pm 8 \cdot 6\end{array}$ & $\begin{array}{r}85 \cdot 5 \pm 8 \cdot 6 \\
96 \cdot 0 \pm 12 \cdot 2\end{array}$ & $\begin{array}{r}87 \cdot 5 \pm 5 \cdot 9 \\
92 \cdot 5 \pm 13 \cdot 2 \\
\end{array}$ \\
\hline Diastolic & $\begin{array}{l}\text { Normals } \\
\text { Toxaemics }\end{array}$ & $\begin{array}{l}\cdots \\
\cdots\end{array}$ & $\begin{array}{l}\ldots \\
.\end{array}$ & $\begin{array}{l}41 \cdot 5=10 \cdot 0 \\
60 \cdot 0=10 \cdot 0\end{array}$ & $\begin{array}{l}56 \cdot 5=11 \cdot 6 \\
68 \cdot 5=10 \cdot 7\end{array}$ & $\begin{array}{l}61 \cdot 5: 7 \cdot 4 \\
71 \cdot 0 \\
13 \cdot 1\end{array}$ \\
\hline
\end{tabular}

\section{Discussion}

The main facts emerging from this investigation may now be considered. (1) The development of the kidney in both groups of infants is the same and, in particular, the glomeruli of the cortico-medullary junction are developed earliest. (2) The urea clearances of both groups are the same but the blood urea concentrations of the toxaemic group are higher than those of the normals. (3) The minute volumes produced in each group are comparable. (4) In the first two days of life the toxaemic babies are hypertensive compared with the normals.

Any explanations of the differences between the two groups of infants must take into account each and all of these facts, and a possible explanation is given by consideration of the work of Trueta, Barclay, Daniel, Franklin, and Prichard (1947) on the renal circulation. The Oxford workers have shown that in certain circumstances a 'by-pass' may come into action in the kidney so that the blood-flow is diverted from the renal cortex and passes into the renal vein through numerous vessels in the cortico-medullary junction. If the cortex remains ischaemic for any length of time, changes occur which result in the development of hypertension. Further, the 'by-pass' consists of the glomeruli and vasa recta of the cortico-medullary junction and these vessels may accommodate all the glomerular blood volume. The variation observed in different animals of the same species was very marked but changes in the cortical blood-flow were always reflected in the blood-flow in the medulla. It would appear possible that the 'by-pass' is open in the toxaemic infants and that this results in mild hypertension; as the glomeruli of the corticomedullary junction are the most fully developed at this stage of life, shunting the blood-flow from the remaining glomeruli does not materially affect the urea clearance or the minute volume. The reduction in the total number of glomeruli in action may, however, cause the blood urea concentration to rise if there is no reserve in these glomeruli. The variation observed by Trueta in animals may well explain the variation seen in all the babies in this series. The 'shunt' theory may be the explanation of the present results, but the ultimate reason for the opening of the shunt remains obscure.

\section{Summary}

The renal function of infants delivered after maternal pre-eclampsia has been investigated and no change in the gross or microscopic anatomy of the kidney could be demonstrated. The urea clearances and the incidence of albuminuria are no different from those in normal babies but the blood urea concentration is higher than normal. On the second day of life the toxaemic babies are slightly hypertensive but this difference has disappeared by 
the fourth day. An attempt is made to explain these findings by reference to Trueta's 'shunt, theory of the renal circulation.

Our thanks are due to Professor W. F. Gaisford for much help and encouragement in the preparation of this paper; to Dr. F. A. Langley for the use of his postmortem material and for the photographs, and to the nursing staff of the hospital for their help in collecting data.

\section{REFERENCES}

Brash, A. A. (1949). Archives of Disease in Childhood, 24, 107.

Browne, F. J., and Dodds, G. H. (1936). Lancet, 1, 1059.

Dexter, L., and Weiss, A. (1941). 'Preeclamptic and Eclamptic Toxemia of Pregnancy; chap. 8. Boston.

Ewald, L. (1916). Mschr. Geburtsh. Gynäk., 43, 347.

Gruenwald, P., and Popper, H. (1940). J. Urol., 43, 452.

Harrison, G. A. (1947). 'Chemical Methods in Clinical Medicine,'3rd ed., p. 98. London.

Haselhorst, G. (1929). Z. Geburtsh. Gynäk., 95, 400.

Huxley, J. S. (1932). 'Problems of Relative Growth,' p. 8. London.
Kampmeier. O. F. (1926). Anat. Rec., 33, 115.

King, E. J. (1946). Micro-Analysis in Medical Biochemistry,' p. 5. 86. London.

McCance, R. A., and Young, W. F. (1941). J. Physiol., Lond., 99, 265.

Norris, G. W., Bazett, H. C., and McMillan, T. M. (1928). ' Blood-Pressure,' 4th ed. London.

Potter, E. L., and Thierstein, S. T. (1943). J. Pediat., $22,695$.

Raubitschek, H. (1914). Beitr. path. Anat., 57, 345.

Rucker, M. P., and Connell, J. W. (1924). Amer. J. Dis. Child., 27, 6.

Salmi, T. (1936). Acta paediatr., Stockh., 18, 92.

Smith, C. A. (1945). 'Physiology of the Newborn Infant.' Springfield, Illinois.

Thomson, J. (1944). Archives of Disease in Childhood, $19,169$.

- (1949). Ibid., 24, 180.

Trueta, J., Barclay, A. E., Daniel, P. M., Franklin, K. J., and Prichard, M. M. L. (1947). 'Studies of the Renal Circulation.' Oxford.

Tyson, R. M., and Bowman, J. E. (1931). Arch. Pediat., 48, 270.

Woodbury, R. A., Robinow, M., and Hamilton, W. F. (1938). Amer. J. Physiol., 122, 472.

Young, W. F., Hallum, J. L., and McCance, R. A (1941). Archives of Disease in Childhood, 16, 243. 